\title{
PENGARUH TERAPI MUROTTAL AL QURAN SURAH MARYAM TERHADAP PENURUNAN TINGKAT KECEMASAN PADA IBU HAMIL TRIMESTER III DI WILAYAH KERJA PUSKESMAS MENINTING
}

\author{
Zulkahfi $^{1}$, Ilham ${ }^{2}$, Nila Kurnia Safitri ${ }^{3}$ \\ ${ }^{1}$ Prodi Ners Stikes Yarsi Mataram \\ 2 Prodi Ners Stikes Yarsi Mataram \\ 3Prodi S.1 Keperawatan Stikes Yarsi Mataram \\ ilhamzhofir@gmail.com
}

\begin{abstract}
ABSTRAK
Kecemasan merupakan respon individu yang ditampakkan terhadap keadaan yang tidak menyenangkan dan dapat dialami oleh semua individu. World Health Organization (WHO) menguraikan bahwa prevalensi global kejadian kecemasan di dunia adalah sebanyak 3,6\%. Menurut Depkes, di Indonesia terdapat 377.000.000 orang ibu hamil yang mengalami kecemasan selama menjalani masa kehamilan dan dapat dirincikan dari 377.000.000 orang ibu hamil tersebut didapatkan kurang lebih 107.000.000 orang ibu hamil yang mengalami peningkatan kecemasan pada trimester III (menjelang persalinan). Penelitian ini bertujuan mengetahui pengaruh terapi Murottal Al-Qur'an Surah Maryam terhadap penurunan tingkat kecemasan pada ibu hamil trimester III. Jenis penelitian ini kuantitatif dengan Rancangan Quasi Experimental Desain dengan pendekatan one group pre and post test without control group. Responden penelitian ini sebanyak 16 responden. Pengukuran kecemasan menggunakan kuesioner Hamilton Rating Scale Aniexty (HRS-A). Penelitian ini menggunakan uji Dependent T-Test untuk menganalisis data. Hasil penelitian ini didapatkan nilai $p$-value $=0,0005<0,05$ menunjukkan adanya pengaruh terapi Murottal Al-qur'an Surah Maryam terhadap penurunan kecemasan pada ibu hamil trimester III. Terapi Murottal Al-Qur'an Surah Maryam dapat menurunkan kecemasan yang dirasakan ibu hamil selama kehamilannya. Rekomendasi institusi dan perawat untuk mengembangkan terapi non-farmakologi untuk menurunkan kecemasan ibu hamil dengan menambahkan intervensi terapi Murottal Al-Qur'an.
\end{abstract}

Kata kunci : kecemasan, murottal Al quran, ibu hamil trimester III.

\section{ABSTRACT}

Anxiety is an individual's response to an unpleasant state that can be experienced by all individuals. The World Health Organization (WHO) outlines that the global prevalence of anxiety events in the world is as much as 3.6\%. According to Depkes, in Indonesia there are 377 million expectant mothers who experience anxiety during pregnancy and can be detailed from the 377 million expectant mothers have received approximately 107 million expectant mothers who have increased anxiety in the III trimester (before childbirth). This research aims to determine the effect of therapy Murottal Al Quran Surah Maryam against the decline in anxiety levels in the pregnant women trimester III. This type of research is quantitatively with experimental design quation with one group pre and post test without control group approach. The respondents were 16 respondents. Measurement of anxiety using the Hamilton Rating Scale (HRS-A) questionnaire. The study used the T-Test Dependent test to analyze the 
data. The results of this study obtained the value of $P$-value $=0.0005<0.05$ indicating the influence of therapy Murottal Al Quran Surah Maryam against the decline of anxiety in the pregnant mother trimester III and can be concluded therapy murottal Qur'an Surah Maryam can decrease the anxiety of the perceived pregnant women during her pregnancy. The results of this research recommend institutions and nurses to develop non-pharmacological therapies to reduce the anxiety of pregnant women by adding therapeutic intervention in Al-Qur'an.

Keywords: anxiety, murottal Al Quran, pregnant women trimester III.

\section{PENDAHULUAN}

Kematian ibu menurut WHO adalah kematian selama kehamilan atau dalam periode 42 hari setelah persalinan atau berakhirnya kehamilan, akibat semua sebab yang terkait dengan atau diperberat oleh kehamilan atau penanganannya, tetapi bukan disebabkan oleh kecelakaan/cedera. Berdasarkan SDKI 2012 angka kematian ibu di Indonesia sebesar 359 per 100.000 kelahiran hidup. Sedangkan angka kematian ibu di NTB tahun 2012 sebesar 251 per 100.000 kelahiran hidup. Berdasarkan laporan dari kabupaten/kota, jumlah kasus kematian ibu di Provinsi NTB selama tahun 2017 adalah 85 kasus, menurun dibandingkan tahun 2016 dengan 92 kasus (Profil kesehatan provisi NTB 2017).

Kecemasan adalah kondisi kejiwaan yang penuh dengan kekhawatiran akan apa yang mungkin terjadi. Menjelang persalinan, tepatnya pada ibu hamil trimester ketiga ibu dibayangi akan persalinan dan mulai muncul kecemasan akan persalinan. Kecemasan menghadapi persalinan menduduki peringkat teratas yang paling sering dialami ibu selama hamil. Seorang calon ibu sering kali dilanda kecemasan menghadapi masa persalinan, hal ini dialami oleh calon ibu yang akan melahirkan bayi pertamanya ataupun yang telah mengalami trauma ketika melahirkan sebelumnya (Wahyuni, 2013).

Banyak sekali dampak negatif yang dapat terjadi apabila selama menjalani masa kehamilan ibu mengalami kecemasan diantaranya yaitu meningkatkan risiko ketidakseimbangan emosional setelah melahirkan, yang sering dikenal dengan istilah baby blues dan depresi postpartum serta lemahnya ikatan kasih sayang (bonding attachment) antara ibu dengan bayi. Selain berdampak negatif terhadap ibu hamil, kecemasan juga berdampak terhadap bayi yang dikandung seperti gangguan tumbuh kembang pada bayi, berat badan lahir rendah (BBLR) dan peningkatan aktifitas Hipotalamus Hipofisis Adrenal (HHA) yang menyebabkan perubahan produksi hormon steroid, rusaknya perilaku sosial dan risiko tinggi terjadinya infertilitas saat dewasa (Shahhosseini, 2015). Adapun tujuan penelitian ini adalah untuk mengetahui pengaruh dari terapi murottal al quran surah maryam terhadap penurunan tingkat kecemasan pada ibu hamil trimester III.

\section{METODOLOGI}

Penelitian ini dilakukan dengan pendekatan kuantitatif dengan desain eksperimen yaitu quasi experimental desain. Rancangan penelitian yang digunakan adalah one group pre and post test without control group desain, dimana sebelum diberi treatment, akan dilakukan pretest, dengan maksud untuk mengetahui keadaan responden sebelum treatment. Kemudian setelah diberikan 
treatment, dilakukan posttest untuk mengetahui keadaan responden setelah treatment. Penelitian telah dilakukan di wilayah kerja Puskesmas Meninting, populasi dalam penelitian ini yaitu semua ibu hamil trimester III di wilayah kerja Puskesmas Meninting yaitu di Desa Batulayar Barat berjumlah 32 orang. Dalam menentukan sampel dalam penelitian ini penulis menggunakan tekhnik Purposive sampling yaitu merupakan tekhnik dalam non-probability sampling. Sampel pada penelitian ini adalah 16 responden.

\section{HASIL PENELITIAN}

1) Tabel 5.1 Distribusi frekuensi responden ibu hamil trimester III di wilayah kerja Puskesmas Meninting berdasarkan usia

\begin{tabular}{|l|c|c|}
\hline \multicolumn{1}{|c|}{ Usia responden } & Jumlah & Presentase (\%) \\
\hline Usia berisiko & 2 & 12,5 \\
\hline Usia tidak berisiko & 14 & 87,5 \\
\hline total & 16 & 100 \\
\hline
\end{tabular}

Berdasarkan tabel 5.1 didapatkan bahwa karakteristik responden berdasarkan usia sebanyak 2 responden $(12,5 \%)$ berada pada usia beresiko dan 14 responden $(87,5 \%)$ berada pada usia tidak beresiko.

2) Tabel 5.2 Distribusi frekuensi responden ibu hamil trimester III di wilayah kerja Puskesmas Meninting berdasarkan paritas

\begin{tabular}{|l|c|c|}
\hline \multicolumn{1}{|c|}{ Paritas } & Jumlah & Presentase (\%) \\
\hline Primipara & 7 & 43,8 \\
\hline Multipara & 9 & 56,2 \\
\hline total & 16 & 100 \\
\hline
\end{tabular}

Berdasarkan tabel 5.2 didapatkan bahwa karakteristik responden berdasarkan paritas yang terbanyak dalam penelitian ini adalah responden dengan multipara yaitu sebanyak 9 responden $(43,8 \%)$ sedangkan responden dengan primipara yaitu sebanyak 7 responden $(56,2 \%)$.
3) Tabel 5.3 Distribusi frekuensi responden ibu hamil trimester III di wilayah kerja Puskesmas Meninting berdasarkan tingkat kecemasan sebelum intervensi

\begin{tabular}{|l|c|c|}
\hline Skala tingkat kecemasan & Jumlah & $\begin{array}{c}\text { Presentase } \\
(\%)\end{array}$ \\
\hline Cemas ringan & 7 & 43,8 \\
\hline Cemas sedang & 5 & 31,2 \\
\hline Cemas berat & 4 & 25,0 \\
\hline total & 16 & 100 \\
\hline
\end{tabular}

Berdasarkan tabel 5.3 menunjukkan bahwa tingkat kecemasan yang dirasakan oleh ibu hamil trimester III sebelum intervensi sebagian besar termasuk dalam kategori cemas ringan $(43,8 \%)$, dan cemas berat $(25,0 \%)$.

4) Tabel 5.4 Distribusi frekuensi responden ibu hamil trimester III di wilayah kerja Puskesmas Meninting berdasarkan tingkat kecemasan setelah intervensi

\begin{tabular}{|l|c|c|}
\hline \multicolumn{1}{|c|}{ Skala tingkat kecemasan } & Jumlah & $\begin{array}{c}\text { Presentase } \\
(\%)\end{array}$ \\
\hline Tidak cemas & 11 & 68,8 \\
\hline Cemas ringan & 3 & 18,7 \\
\hline Cemas sedang & 2 & 12,5 \\
\hline total & 16 & 100 \\
\hline
\end{tabular}

Berdasarkan tabel 5.4 menunjukkan bahwa tingkat kecemasan yang dirasakan ibu hamil trimester III setelah intervensi sebagian besar kecemasan berada pada kategori tidak cemas yaitu sebanyak 11 responden $(68,8 \%)$. Sedangkan tingkat kecemasan paling sedikit berada pada kategori cemas sedang yaitu sebanyak 2 responden $(12,5 \%)$. Dan untuk kategori cemas ringan yaitu sebanyak 3 responden $(18,7 \%)$.

5) Tabel $5.5 \quad$ Pengaruh Terapi Murottal Al Quran Surah Maryam Terhadap Penurunan Tingkat Kecemasan Pada Ibu Hamil Trimester III Di Wilayah KerjaPuskesmas Meninting 


\begin{tabular}{|l|c|c|c|c|c|}
\hline $\begin{array}{c}\text { Kecemasan } \\
\text { Ibu hamil } \\
\text { TM III }\end{array}$ & Mean & SD & SE & Pvalue & N \\
\cline { 1 - 4 } $\begin{array}{l}\text { Sebelum } \\
\text { intervensi }\end{array}$ & 11 & 5,89 & 1,47 & 0,0005 & 16 \\
\hline $\begin{array}{l}\text { Setelah } \\
\text { Intervensi }\end{array}$ & 3 & 4,58 & 1,14 & & \\
\hline
\end{tabular}

Berdasarkan tabel 5.5 Hasil uji statistik yang telah dilakukan dengan menggunakan uji dependent t-test didapatkan bahwa nilai $P=0,0005$. Karena nilai $\mathrm{P}=0,000$ yang berarti nilainya $<0,05$ maka dapat diambil kesimpulan bahwa ada pengaruh pemberian terapi murottal Al Quran surah Maryam terhadap penurunan tingkat kecemasan pada ibu hamil trimester III sebelum dan setelah intervensi.

\section{PEMBAHASAN}

Sebelum dilakukan intervensi murottal Al-Qur'an Maryam terhadap ibu hamil trimester III didapatkan ratarata skor kecemasan ibu sebelum diberikan intervensi yaitu 22,75 dan rata rata skor kecemasan setelah di berikan intervensi yaitu 13,6. Penurunan skor kecemasan dalam penelitian ini \pm 9 poin dimana skor sebelum intervensi berada pada 22,75 dan skor setelah intervensi berada pada 13,6 . Penelitian ini sejalan dengan penelitian sebelumnya yang dilakukan oleh Riza Wahyuni (2013) menyatakan bahwa hasil penelitian yang dilakukan didapatkan ada pengaruh murottal Al Quran terhadap kecemasan ibu hamil trimester III dengan $p$ value= $0,007(<0,05)$.

Hasil penelitian ini dapat diketahui bahwa dengan melakukan terapi murottal Al-Qur'an pada ibu hamil trimester III selama 14 hari dapat menurunkan skor kecemasan dengan rata-rata 13,6. Hasil ini menunjukkan bahwa intervensi terapi murottal AlQur'an Surah Maryam terhadap kecemasan ibu hamil trimester III memberikan hasil yang positif dengan penurunan skor kecemasan hingga \pm 9 poin.

Terapi murottal Al-Quran dengan bacaan yang benar dan keteraturan irama akan mampu mendatangkan ketenangan dan meminimalkan kecemasan bagi mereka yang mendengarnya. Terapi ini juga dapat memberi motivasi dan memberi kekuatan untuk menghadapi masalah yang sedang dihadapi sehingga terapi ini dapat menurunkan ketegangan, menstabilkan tekanan darah dan membuat ibu menjadi lebih tenang dalam menghadapi kecemasannya (Wahyuni, 2013).

Hasil uji statistik yang digunakan dalam penelitian ini yaitu dependent $t$ test didapatkan bahwa nilai $p$ value $=$ 0,0005 Karena nilai $p=0,000<0,05$ dapat diambil kesimpulan bahwa ada perbedaan yang bermakna terhadap skor kecemasan sebelum dan sesudah intervensi sehingga $\mathrm{H} 1$ diterima yang berarti "Murottal Al-Qur'an Surah Maryam Berpengaruh Terhadap Penurunan Skor Kecemasan Ibu Hamil Trimester III di Wilayah Kerja Puskesmas Meninting". Penelitian ini sejalan dengan penelitian yang dilakukan Budiarti (2018) menyatakan bahwa terapi murottal Al Quran berhasil menurunkan kecemasan ibu hamil primigravida trimester III.

Dari hasil observasi didapatkan data bahwa ibu hamil yang telah dilakukan terapi murottal Al-Qur'an surah Maryam oleh peneliti selama 14 hari telah mengalami penurunan skor kecemasan. Hasil rata-rata skor kecemasan ibu hamil mengalami penurunan yaitu dari 22,75 ke 13,6 . Hasil ini menunjukan bahwa intervensi terapi Murrotal Al-Quran Surah Maryam memberikan hasil yang positif terhadap responden dan signifikan dalam penelitian. Ernawati (2013) menyatakan bahwa suara Al-Qur'an 
(Murottal) ibarat gelombang suara yang memiliki ketukan dan gelombang tertentu, menyebar dalam tubuh kemudian menjadi getaran yang bisa mempengaruhi fungsi gerak sel otak dan membuat keseimbangan didalamnya.

Menurut Campbell (2001)

berbagai tempo musik mempunyai efek fisiologis pada tubuh, salah satu efeknya adalah mempengaruhi denyut jantung dan tekanan darah sesuai frekuensi, tempo, dan volumenya. Jantung cenderung mengikuti dan mencoba menyamai tempo suatu bunyi.Volume yang bisa menimbulkan efek teraupetik adalah 40-60 dB. Sedangkan waktu yang dibutuhkan dalam auditoris therapy (terapi pendengaran) supaya dapat memberikan efek terapeutik adalah minimal 10 menit.

Berdasarkan hasil penelitian Wahyuni (2013) bahwa terapi murottal Al-Qur'an dapat dijadikan sebagai penyembuh sakit. Telah dibuktikan dan dilakukan oleh orang yang membaca Al-Qur'an atau mendengarkannya akan memberikan perubahan arus listrik di otot, perubahan sirkulasi darah, perubahan detak jantung dan perubahan kadar darah pada kulit. Pemberian terapi murrotal Al-Quran surah Maryam ini terbukti dapat berpengaruh pada penurunan skor kecemasan dikarenakan efek dari terapi murrotal Al-Quran surah Maryam ini memiliki ketenangan dan rileks sehingga siapa saja yang mendengarkannya dapat memberikan respon positif dan sakit yang dirasakan dapat sedikit berkurang. Sehingga peneliti mengembangkan terapi nonfarmakologi untuk menurunkan kecemasan ibu hamil dengan menambahkan intervensi terapi murottal Al-Qur'an dengan menggunakan suara qori' yang telah familiar di masyarakat luas bahkan orang awam sekalipun.

\section{DAFTAR PUSTAKA}

Budiarti,Yuliani \& Makiah. 2018. Pengaruh Terapi Murottal Al Quran Terhadap Tingkat Kecemasan Ibu Hamil Primigravida Trimester III Di Wilayah Puskesmas Pekauman. Jurnal Citra Keperawatan. Volume 6, No. 2, Desember 2018. Campbell, Don. 2001. Efek Mozart, memanfaatkan kekuatan music untuk mempertajam pikiran, meningkatkan kreativitas dan menyehatkan tubuh. Penerjemah T HErmaya, Cetakan I Januari, Gramedia Pustaka Utama, Jakarta.

Dinas Kesehatan Provinsi Nusa Tenggara Barat. 2017. Profil Kesehatan NTB 2017. www.kemkes.go.id. Diakses Pada 03 Desember 2019.

Ernawati. 2013. Pengaruh mendengarkan Murottal Q.S Ar Rahman terhadap tekanan darah pada pasien hipertensi di Rumah Sakit Nur Hidayah Yogayakarta. Universitas Muhammadiyah Yogyakarta.

Shahhosseini Z, Pourasghar M, Khalilian A, Salehi F. 2015. A Review of the Effect of Anxiety During Pregnancy on Children's Health. Mater Sociomed. 27 (3): 200-202.

Shodiqoh ER, Syahrul F. 2014. Perbedaan Tingkat Kecemasan Dalam Menghadapi Persalinan Antara Primigravida dan Multigravida. Jurnal Berkala Epidemiologi. 2 (1): 141-150.

Sadock BJ, Sadock VA, Ruiz P. 2015. Kaplan Sadock's Synopsis of Psychiatry: Behavioral Sciences/Clinical Psychiatry. Edisi 11. Wolters Kluwer Health. New York-USA.

Wahyuni, Riza, Dkk. 2013. Pengaruh Terapi Murottal Terhadap Tingkat 
NILA KURNIATI SAFITRI

kecemasan Menghadapi

Persalinan Pada Ibu Hamil.

Volume 9, No 2, Oktober 2013 :

111-122. 